\title{
AMMONIA EMISSION AND MOISTURE EVAPORATION FROM CATTLE MANURE WITH DIFFERENT MOISTURE AND EXCREMENT CONTENT
}

\author{
Vladislav Gordeev, Tatiana Mironova, Viacheslav Mironov \\ Federal Scientific Agroengineering Centre VIM, Russia \\ cow-sznii@yandex.ru
}

\begin{abstract}
Ammonia emission and moisture evaporation from manure affect the climate inside the cow barn. According to our previous study, the manure surface area is of greater importance than its layer thickness in this respect. However, in practice, the manure passage area cannot be reduced in the loose housing of cows in cubicles. Therefore, other factors contributing to emission abatement are to be considered. The study objective was to identify the relation between the ammonia emission and moisture evaporation from cattle manure and the manure moisture and excrement content. For this purpose, a laboratory-scale set-up was designed. It consisted of a case with a fan installed and an exhaust pipe with a gas detector and an air velocity transmitter. The initial relative moisture content of cow excrement was $89 \%$. Peat with $57 \%$ moisture content was added to reduce it, and tap water was added to increase it. The mass of each sample was $1 \mathrm{~kg}$. In the experiment, the tested sample was placed in the set-up; the air was blown over its surface by the fan and the sensors in the pipe recorded the ammonia concentration and the airflow rate. Each experiment lasted for 30 minutes. The ammonia emission was calculated by the common methodology. The moisture evaporation was determined by the change in the sample mass during the experiment. The study results showed that the average ammonia emission from the initial excrement with $89 \%$ moisture content was $68.26 \mathrm{mg} \cdot \mathrm{h}^{-1}$. When peat was added and the mixture moisture content reduced to $84 \%$, the average ammonia emission was $41.57 \mathrm{mg} \cdot \mathrm{h}^{-1}$. When water was added and the mixture moisture content increased to $94 \%$, the average ammonia emission was $32.93 \mathrm{mg} \cdot \mathrm{h}^{-1}$. In terms of the excrement unit, the ammonia emission decreased by $30.1 \%$ when peat was added and only by $9 \%$ when water was added. Therefore, the animal housing on bedding is preferable to reduce the ammonia emission from manure and to create a more favorable climate in the cow barn.
\end{abstract}

Keywords: manure, ammonia emission, moisture evaporation, microclimate, cow barn.

\section{Introduction}

Milk production has one important by-product - cattle manure. Physical, chemical and biological processes in manure result in gas release and moisture evaporation affecting the environment and health. In the EU countries, the agricultural sector is the source of above $94 \%$ of the total anthropogenic emissions of ammonia, of which manure removal systems account for $56 \%$ [1].

The shift in the animal feeding strategy may be an abatement measure [2]. However, manure management improvements are considered more efficient in this respect [3].

Lowering the cow barn temperature and the airflow rate above the manure surface [4-6], as well as cutting the manure-soiled area $[7 ; 8]$ may reduce the ammonia emissions. The laboratory tests have verified the effect of these factors. It was established that higher air and manure surface temperature resulted in an exponential increase in ammonia emissions [5], while the dependence of emission on the air velocity was best expressed by a second-degree polynomial [4]. At the same time, excessive ventilation reduction leads to the indoor air quality degradation [9]. The manure surface area has a more significant effect on ammonia emission and moisture evaporation than the manure layer thickness [8; 10]. When the manure-soiled area increased three-fold, the average ammonia emission increased by 2.9 times, whereas when the manure layer thickness changed by $15 \mathrm{~mm}$, the emission increased only up to $5.5 \%$ [8]. However, it is impossible to reduce the area of manure passages in the loose housing of cows in cubicles. Therefore, other factors contributing to emission abatement need to be identified.

The release of gases from manure depends on its temperature and humidity $[11 ; 12]$. One of the previous studies focused on the tests with cattle manure, using a laboratory setup in the form of a sealed chamber [12]. The livestock houses, however, must have ventilation that promotes the constant air exchange and inside airflow.

This study aimed to investigate the ammonia emission and moisture evaporation from cattle manure depending on its moisture and excrement content in the conditions closer to the real ones on 
the specially designed laboratory set-up. The data obtained can be used for related calculations in particular livestock houses and ventilation systems.

\section{Materials and methods}

A laboratory setup [10] was used to study the ammonia emission from cattle manure. It consisted of a case and an exhaust pipe. The case was a chamber of $0.089 \mathrm{~m}^{3}$ with a fan. An exhaust pipe with an Astra-D ammonia gas detector and EE65-VCK 500 air velocity transmitter was installed opposite the fan. A Paragraph electronic recorder transmitted the data to the computer. The MX-50 humidity analyser determined the moisture content of tested materials with the measurement accuracy of $0.01 \%$.

The average temperature in the chamber during the experiments was $22.6{ }^{\circ} \mathrm{C}$; the airflow rate over the sample surface was $0.16 \mathrm{~m} \cdot \mathrm{s}^{-1}$.

The samples of cow excrements were collected into special sealed containers from the manure passage along its entire width in one of the farms in Leningrad Region with typical cow barns. The farm had the loose housing of cows in cubicles on rubber mats. The average productivity of the dairy cows was above $7000 \mathrm{~kg} \cdot$ head $^{-1} \cdot \mathrm{year}^{-1}$. The sampling material was thoroughly mixed before being analysed.

The initial relative moisture content of cow excrement was $89 \%$. Tap water was added to increase it. In terms of water retention, cattle manure is similar to organic peat soil [13]. Therefore, high-bog poorly decayed peat with at least $85 \%$ organic matter content, $\mathrm{pH} 5.5-6$ and 0-20 mm fractions was added to reduce the manure moisture content. Before the study, the peat moisture content was measured to be $57 \%$.

The formula [14] allowed calculating the amount of material (water or peat) to be added to the source excrement to obtain a mixture with the moisture content complying with the experimental conditions:

$$
Q_{\text {mat }}=\left(W_{\text {exc }}-W_{\text {mix }}\right) /\left(W_{\text {mix }}-W_{\text {mat }}\right),
$$

where $Q_{\text {mat }}$ - amount of material to be added to the unit excrement to obtain the mixture of required moisture content;

$W_{\text {exc }}, W_{\text {mat }}, W_{\text {mix }}$ - relative moisture content of excrement, added material and their mixture, correspondingly.

The same amount of manure of different moisture content was tested. The mass of each sample was $1 \mathrm{~kg}$. The excrement content in the samples depending of the manure moisture content was $87 \%$ when peat was added (Sample 1), $100 \%$ in the source excrements (Sample 2) and $53 \%$ when water was added (Sample 3).

The samples were put into a $0.09 \mathrm{~m}^{2}$ tray one at a time and placed in the laboratory setup chamber; the installed fan forced the airflow above the sample surface, and the sensors in the pipe recorded the ammonia concentration and the airflow rate. Each experiment lasted for 30 minutes, as the farm manure removal conveyors are usually switched on every 30 to 60 minutes. The ammonia concentration was recorded every 15 seconds. Each experiment version had three replications.

The ammonia emission was calculated for each of ammonia concentration values [15]. The common methods of mathematical statistics were applied to analyse the results. The average ammonia emission was calculated depending on the excrement content.

The moisture evaporation was determined by the change in the sample mass during the experiment. Before and after each experiment, CAS SW-5 scales weighed the tray with the sample with the resolution of $2 \mathrm{~g}$.

\section{Results and discussion}

In the study, the smallest registered ammonia concentration was $0.99 \mathrm{mg} \cdot \mathrm{m}^{-3}$, and the biggest one $-2.47 \mathrm{mg} \cdot \mathrm{m}^{-3}$. The maximum value was obtained in Sample 2 with $89 \%$ initial moisture content. The average calculated values of ammonia emission and moisture evaporation from the samples are presented in Table 1. 


\section{Experiment results}

\begin{tabular}{|c|c|c|c|c|}
\hline $\begin{array}{c}\text { Samp } \\
\text { le }\end{array}$ & $\begin{array}{c}\text { Sample moisture } \\
\text { content, \% }\end{array}$ & $\begin{array}{c}\text { Excrement } \\
\text { content, \% }\end{array}$ & $\begin{array}{c}\text { Ammonia } \\
\text { emission, } \\
\mathbf{m g} \cdot \mathbf{h}^{-\mathbf{1}}\end{array}$ & $\begin{array}{c}\text { Mass change, } \\
\mathbf{g} \cdot \mathbf{h}^{\mathbf{- 1}}\end{array}$ \\
\hline 1 & 84 & 0.87 & 41.57 & 0.0126 \\
\hline 2 & 89 & 1 & 68.26 & 0.0129 \\
\hline 3 & 94 & 0.53 & 32.93 & 0.0145 \\
\hline
\end{tabular}

The study results showed that the average ammonia emission from the manure mixed with peat and $84 \%$ moisture content was $41.57 \mathrm{mg} \cdot \mathrm{h}^{-1}$, from the initial excrement with $89 \%$ moisture content $68.26 \mathrm{mg} \cdot \mathrm{h}^{-1}$, and from the manure with water added and $94 \%$ moisture content $-32.93 \mathrm{mg} \cdot \mathrm{h}^{-1}$ (Fig. 1).

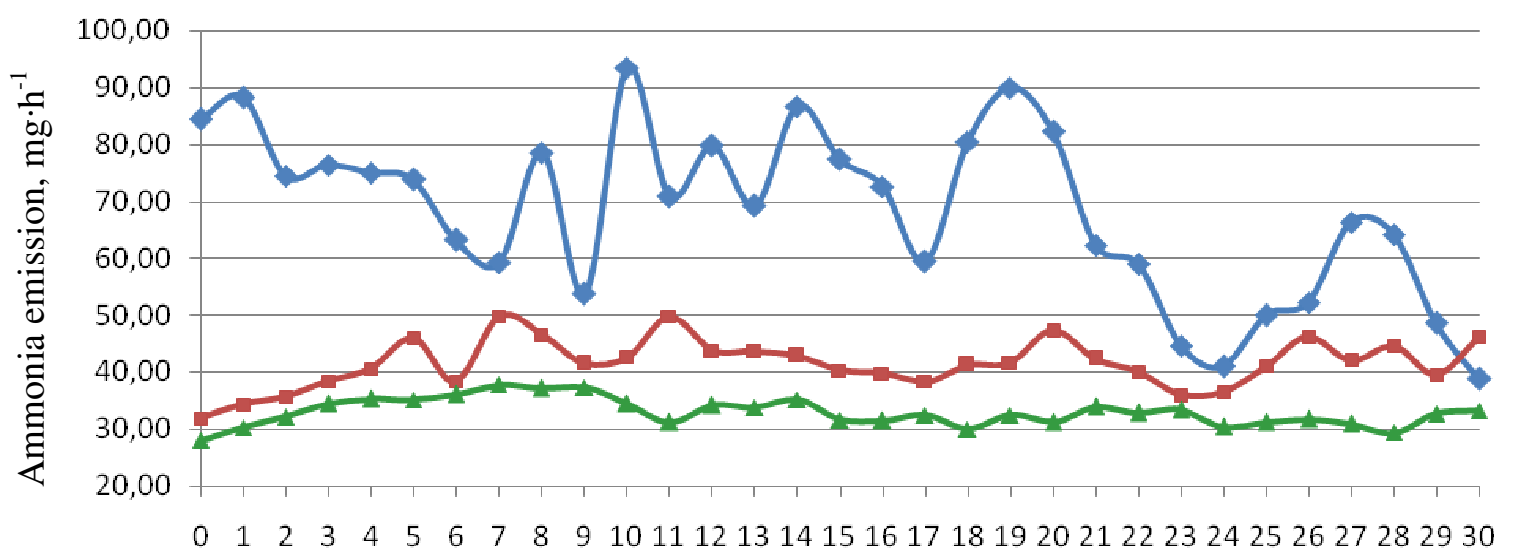

Fig. 1. Ammonia emission from tested material:

Time, min.

$\rightarrow-$ Sample 1, $\multimap-$ Sample 2, $\longleftarrow-$ Sample 3

There was a tendency towards the dependence of ammonia emission on the excrement content in the tested samples. With a decrease in the excrement content in the sample weighing $1 \mathrm{~kg}$, the ammonia emission from manure also decreased. When $13 \%$ of peat was added to the initial excrement to reduce the manure moisture content to $84 \%$, the ammonia emission from $1 \mathrm{~kg}$ of the resulting mixture decreased by $28.4 \%$; when $47 \%$ of water was added - by $48.2 \%$.

In terms of the excrement unit, when peat was added to obtain $84 \%$ moisture content, the ammonia emission was $47.7 \mathrm{mg} \cdot \mathrm{h}^{-1}$ (Fig. 2) that was $30.1 \%$ less than the data obtained from the initial excrement with $89 \%$ moisture content. When water was added to obtain $94 \%$ moisture content, the ammonia emission was $62.1 \mathrm{mg} \cdot \mathrm{h}^{-1}$ that was only $9 \%$ less than the data from the initial excrement.

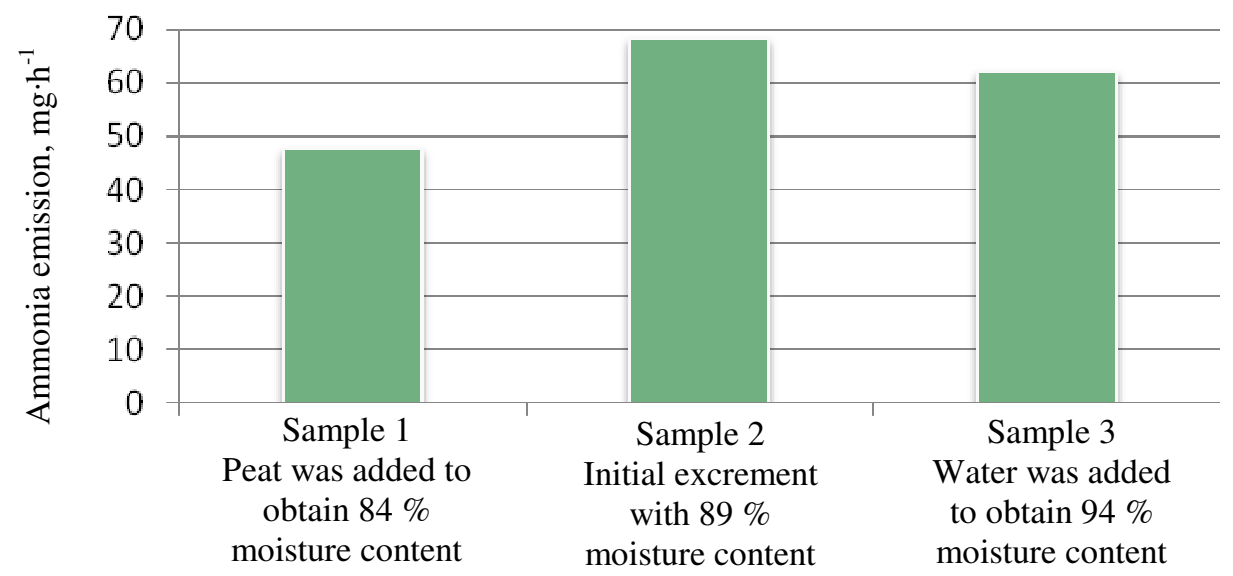

Fig. 2. Ammonia emission in terms of $1 \mathrm{~kg}$ of excrement 
The addition of peat was also beneficial in terms of reducing moisture evaporation. Under the lower manure moisture content, the mass-change value due to moisture evaporation decreased. When the manure moisture content was $84 \%$, the moisture evaporation from the sample was $0.0126 \mathrm{~g} \cdot \mathrm{h}^{-1}$.

The results of this study are consistent with the findings previously published by other authors [6], who recommend promoting the manure surface drying and crust formation both in natural conditions and using artificial means, such as bedding, to reduce ammonia emissions from manure.

\section{Conclusions}

According to the experimental data and in terms of the excrement unit, the ammonia emission decreased by $30.1 \%$, when peat was added, and only by $9 \%$, when water was added. The study data indicate that the animal housing on bedding with resulting solid manure is more preferable from the standpoint of lower ammonia emissions from manure and more favourable microclimate in the cow barn.

\section{References}

[1] Ortiz A., Guerreiro C, de Leeuw F., Horálek J. Air Quality in Europe - 2017 report. Copenhagen: European Environment Agency. 2017. 74 p. DOI: 10.2800 / 358908.

[2] Hristov A.N. Diet formulation as an effective tool for mitigating nitrogen excretion in dairy systems. Advances in Animal Biosciences. Vol. 4, Special Issue s1 (Proceedings of the Dairy Solutions Symposium, 20th - 21st June 2012, University College Dublin, Dublin, Ireland), 2013, pp. 15-18.

[3] Wei S., Bai Z.H., Chadwick D., Hou Y., Qin W., Zhao Z.Q., Jiang R.F., Ma L. Greenhouse gas and ammonia emissions and mitigation options from livestock production in peri-urban agriculture: Beijing - A case study. Journal of Cleaner Production, vol. 178, 2018, pp. 515-525. DOI:10.1016/j.jclepro.2017.12.257

[4] Bleizgys R., Bagdoniene I. Control of ammonia air pollution through the management of thermal processes in cowsheds. Science of The Total Environment, 568, 2016, pp. 990-997. DOI: 10.1016/j.scitotenv.2016.05.017

[5] Bleizgys R., Bagdonienė I., Baležentienè L. Reduction of the livestock ammonia emission under the changing temperature during the initial manure nitrogen biomineralization. The Scientific World Journal, 2013, vol. 2013, 7 p. DOI: 10.1155/2013/825437.

[6] Bagdonienè I., Bleizgys R. Ammonia emissions from dairy cattle manure under variable ventilation rates. Annals of Animal Science, vol. 14, 2014, pp. 141-151. DOI: 10.2478/aoas-20130084 .

[7] Groenestein C.M., Valli L., Piñeiro Noguera C., Menzi H., Bonazzi G., Döhler H., Van der Hoek K., Aarnink A.J.A., Oenema O., Kozlova N., Kuczynski T., Klimont Z., Montalvo Bermejo G. Livestock housing. Options for Ammonia Mitigation Guidance from the UNECE Task Force on Reactive Nitrogen. Edinburgh. 2014. pp. 14-25.

[8] Gordeev V.V., Mironova T.Yu., Lantsova E.O. Ammonia emissions from cattle manure versus its quantity. Engineering for Rural Development 17th International Scientific Conference, Jelgava, 2018, pp. 261-264. DOI: 10.22616/ERDev2018.17.N298.

[9] Kang J.H., Lee S.J. Improvement of natural ventilation in a large factory building using a louver ventilator. Building and Environment, 43 (12), 2008, pp. 2132-2141.

DOI: 10.1016/j.buildenv.2007.12.013.

[10]Гордеев В.В., Миронова Т.Ю., Ильин Р.М. Исследования выделения влаги из навоза КРС. (Study of moisture release from cattle manure). Technologies, machines and equipment for mechanised crop and livestock production: Технологии и технические средства механизированного производства продукции растениеводства и животноводства. 2018. No 96. pp. 243-250. DOI: 10.24411/0131-5226-2018-100579. (In Russian).

[11] Hu E., Sutitarnnontr P., Tuller M., Jones S. Modeling temperature and moisture dependent emissions of carbon dioxide and methane from drying dairy cow manure. Frontiers of Agricultural Science and Engineering, 2018, No 5, pp. 280-286. DOI: 10.15302/J-FASE2018215. 
[12]Вторый С.В., Ланцова Е.О. Влияние температуры воздуха и влажности навоза на интенсивность эмиссии газов из навоза крупного рогатого скота (The effect of air temperature and manure humidity on the intensity of gas emission from cattle manure). Regional Ecology: Региональная экология, 2015, No 5 (40), pp. 43-45. (In Russian).

[13] Sutitarnnontr P., Hu E., Tuller M., Jones S. Physical and thermal characteristics of dairy cattle manure. Journal of Environmental Quality, 43, 2014, pp. 2115-2129. DOI: $10.2134 /$ jeq2014.05.0212.

[14]Хазанов Е.Е., Гордеев В.В., Хазанов В.Е. Технология и механизация молочного животноводства (Technology and mechanisation of dairy farming). Saint Petersburg: Lan Publ.: СПб, Лань, 2016. 352 p. (In Russian).

[15]Брюханов А.Ю., Козлова Н.П., Максимов Н.В. Способ определения и мониторинга величины массовых выбросов загрязняющих веществ в окружающую среду из животноводческого помещения и система его осуществления (Method to determine and monitor the amount of mass emissions of pollutants into the environment from livestock premises and the system for its implementation). Patent RF No. 2477886. 2013. (In Russian). 